Aliza Amiel • Federica Sardos-Albertini

Moshe D. Fejgin • Reuven Sharony • Roni Diukman

Benjamin Bartoov

\title{
Interchromosomal effect leading to an increase in aneuploidy in sperm nuclei in a man heterozygous for pericentric inversion (inv 9) and C-heterochromatin
}

Received: December 12, 2000 / Accepted: January 19, 2001

\begin{abstract}
We describe a man with pericentric inversion 9 and constitutive heterochromatin, and a high disomy rate in his sperm cells (with all probes analyzed). The disomy rate was estimated with the following probes: $8,9,18, \mathrm{X}$, and $\mathrm{Y}$, and was significantly higher than that in control sperm cells, while chromosome 9 showed the highest disomy frequency. The probes of $\mathrm{X}$ and $\mathrm{Y}$ together showed the same disomy frequency as $\mathrm{X}$ and $\mathrm{Y}$ alone, which indicates the same nondisjunction rate in the first meiotic division. We suggest that the interchromosomal effect found in this man differed from other findings in sperm cells of men carrying an inversion in terms of the difference in the length of the heterochromatin between the two chromosomes 9. Also, it is well known that the effect of inversion 9 with increased heterochromatin is highly variable and may even vary in members of the same family.
\end{abstract}

Key words Interchromosomal effect · Inversion (9) · FISH · Aneuploidy $\cdot$ Disomy $\cdot$ Heterochromatin

\section{Introduction}

Pericentric chromosomal inversions are common in humans, with a reported frequency of $1 \%-2 \%$ (De La Chapelle et al. 1974; Kaiser 1984). Some chromosomal inversions can give rise to the birth of an abnormal child, resulting from duplications and deficiencies of a recombinant chromosome, whereas other inversions seem compatible with the transmission of only normal and genetically

A. Amiel $(\bowtie) \cdot$ F. Sardos-Albertini $\cdot$ M.D. Fejgin $\cdot$ R. Sharony Genetic Institute, Meir Hospital, Kfar-Saba 44281, Israel

Tel. +972-9-747-2220; Fax +972-9-741-9851

e-mail: alizaamiel@hotmail.com

R. Diukman

Department of Obstetrics and Gynecology, Lady Davis Carmel Medical Center, Haifa, Israel

B. Bartoov

Life Science Faculty, Bar-Ilan University, Ramat-Gan, Israel balanced offspring for generations. It has been shown that, in order for an individual heterozygote for a pericentric inversion to produce a live-born child with a recombinant chromosome, the inverted segment must involve a minimum of 30\% (Winsor et al. 1978) or one-third (Trunca and Opitz 1977) of the chromosome length. Overall, the risk that a carrier of a pericentric inversion will produce a child with an unbalanced karyotype is $1 \%-10 \%$ (Gardner and Sutherland 1996). The most frequent pericentric inversion in humans is $\operatorname{inv}(9)(\mathrm{p} 11 \mathrm{q} 13)$, with a frequency of $0.95 \%$ in the general population (Gardner and Sutherland 1996). Although the inversion of the long arm heterochromatic region ( $\mathrm{qh}$ ) of chromosome 9 can be considered as a normal polymorphism, its clinical consequences remain unclear. While some studies seem to reveal a direct association of $\operatorname{inv}(9 \mathrm{qh}+)$ with infertility and repeated abortions, as a result of abnormal disjunction at meiosis or early arrest of zygote development, other studies exclude any association (reviewed in Serra et al. 1990). Serra et al. (1990) suggested that the inversion $\operatorname{inv}(9)(\mathrm{qh})$ could interfere with the correct segregation during meiosis of chromosomes not involved in the inversion, leading to an increase in aneuploidy of the gametes.

Ford et al. (1982) studied the possible associations of alterations in chromosome 9 heterochromatin with reproductive loss, and found that one of the chromosomes 9 was significantly larger in subjects with histories of recurrent fetal loss, a finding not observed in a control group (Ford et al. 1982). However, Ford et al. (1982) were unable to determine whether this association was due to the difference in size between the pair of homologous chromosomes or whether it was due to the size of the larger chromosome in mitotic cell division. A number of reports have documented an excess of chromosomal variants, especially of chromosome 9 with inv(9) and $9 \mathrm{qh}+$, in couples with reproductive failure (De La Chapelle et al. 1974; Holbek et al. 1974; Nielsen et al. 1974; Boue et al. 1975; Tsenghi et al. 1981; Rosenmann et al. 1977; Tibiletti et al. 1981; Ford et al. 1982; Ford and Lester 1982; Gabriel-Robez et al. 1987; Fryns et al. 1984). In contrast to these findings, other authors did not find any significant differences in the frequency of such 
polymorphic variants when comparing control groups with reproductive failure couples (Hemming and Burns 1979; Blumberg et al. 1982; Maes et al. 1983), leading them to conclude that chromosomal polymorphic variants do not play an important role in the etiology of recurrent fetal wastage. It seems that the effect of $\operatorname{inv}(9)(\mathrm{qh})$ is highly variable even in members of the same family (Serra et al. 1980; Wang and Hamerton 1979). In the past decade, several studies were conducted analyzing human sperm karyotypes for the presence of possible aneuploidy in individuals known to carry an inversion (of chromosomes 1, 3, 7, 8, 9, 14, and 20). No interchromosomal effect (for any inversion studied) was demonstrated in any of these studies (Colls et al. 1997; Guttenbach et al. 1997; Martin 1991, 1999; Martin et al. 1993, 1994; Navarro et al. 1993).

In the present study, we demonstrate an increased risk for interchromosomal effect (presented as a high rate of sperm disomy) in a man carrying a pericentric inversion of chromosome 9 and a larger $\mathrm{C}$-heterochromatin in one of the chromosomes.

\section{Subjects and methods}

A 31-year-old woman, married to a 33-year-old healthy man, presented in her second pregnancy; genetic amniocentesis was performed following an abnormal secondtrimester biochemical triple screen. Her first pregnancy had ended in a first-trimester spontaneous abortion.

The fetal karyotype was 47,XY,inv $(9 \mathrm{qh}+),+21 /$ $46, \mathrm{XY}, \operatorname{inv}(9 \mathrm{qh}+)$, with a mosaicism rate of $45 \%$. The couple opted to terminate the pregnancy. The fetal leukocyte karyotype was $47, \mathrm{XY}, \operatorname{inv}(9 \mathrm{qh}+),+21 / 46, \mathrm{XY}, \operatorname{inv}(9 \mathrm{qh}+)$, with $15 \%$ mosaicism. The couples' karyotypes were analyzed. While the woman's was normal, the man's karyotype was $46, X Y, \operatorname{inv}(9 q h+)$. Of note was that the man was healthy, was not on any medication, and did not use drugs.

\section{Probes}

For chromosome 8: CEP $8 \alpha$ satellite DNA, D8Z2 spectrum, orange

For chromosome 9: CEP $9 \alpha$ satellite DNA, spectrum, green

For chromosome 18: CEP 18 a satellite DNA, D18Z1, spectrum orange

For X chromosome: CEP X $\alpha$ satellite DNA, DXZ1, spectrum, green

For Y chromosome: CEP Y $\alpha$ satellite DNA, DYZ3, spectrum, orange

\section{Pretreatment of sperm nuclei (decondensation)}

Slides were incubated in a small volume $(100 \mu \mathrm{l})$ of freshly diluted $10 \mathrm{mM}$ dithiothreitol (Sigma, St. Louis, MD, USA) in $0.05 \mathrm{M}$ Tris buffer at $-4^{\circ} \mathrm{C}$ for $25-50 \mathrm{~min}$. After incubation, the slides were washed twice with $2 \times$ saline sodium citrate $(2 \times$ SSC: $0.15 \mathrm{M} \mathrm{NaCl}, 0.015 \mathrm{M}$ sodium citrate $)$ for $10 \mathrm{~min}$, passed through a cold ethanol series $(70 \%, 80 \%$, $100 \%$ ), air-dried, and observed under phase-contrast microscopy.

Mono- and dual-color fluorescence in situ hybridization (FISH)

Slides were first denatured in $70 \%$ formamide, $2 \times$ SSC at $73^{\circ} \mathrm{C}$ for $2 \mathrm{~min}$. Prior to hybridization, the labeled probes in the hybridization mixture were heated to $75^{\circ} \mathrm{C}$, and put on ice. The hybridization mixture $(10 \mu \mathrm{l})$ was applied to each slide under a coverslip, and hybridization proceeded overnight at $37^{\circ} \mathrm{C}$; after incubation, the slides were washed at $42^{\circ} \mathrm{C}$ in $70 \%$ formamide, $2 \times \mathrm{SSC}$ for $20 \mathrm{~min}$, then in $2 \times \mathrm{SSC}$ for $10 \mathrm{~min}$, and finally in $4 \times \mathrm{SSC}, 0.1 \%$ Tween- 20 for $5 \mathrm{~min}$.

Random aneuploidy in leukocytes and sperm disomy were assessed using a direct FISH technique (mono- and dual-color) in the husband and in two fertile men who served as controls. Mono-color FISH was performed using Vysis (Downers Grove, IL, USA) probes for chromosomes 8,9 , and 18 on sperm and leukocyte nuclei in order to prevent any overlapping between the different probes (due to the small size of the sperm cells, because the samples were left over from the infertility laboratory). In order to find out in which meiotic division the nondisjunction occurred, dual-color FISH was performed using Vysis probes for $\mathrm{X}$ and $\mathrm{Y}$. Also, in order to rule out sperm diploidy, Vysis probes for chromosomes 9 and 18 were used together (Fig. 1) (Spriggs et al. 1995).

A total of 12,146 sperm cells and 824 leukocytes from the man carrying the inversion, as well as 24,026 sperm cells and 1645 leukocytes from the two control individuals, were examined, using an Olympus BX50 epifluorescence microscope (Olympus, Tokyo, Japan) equipped with a triple bandpass filter for 4' -6' -diamindino-2-pherylindole (DAPI) Texas red and fluorescein isothiocyanate (FITC).

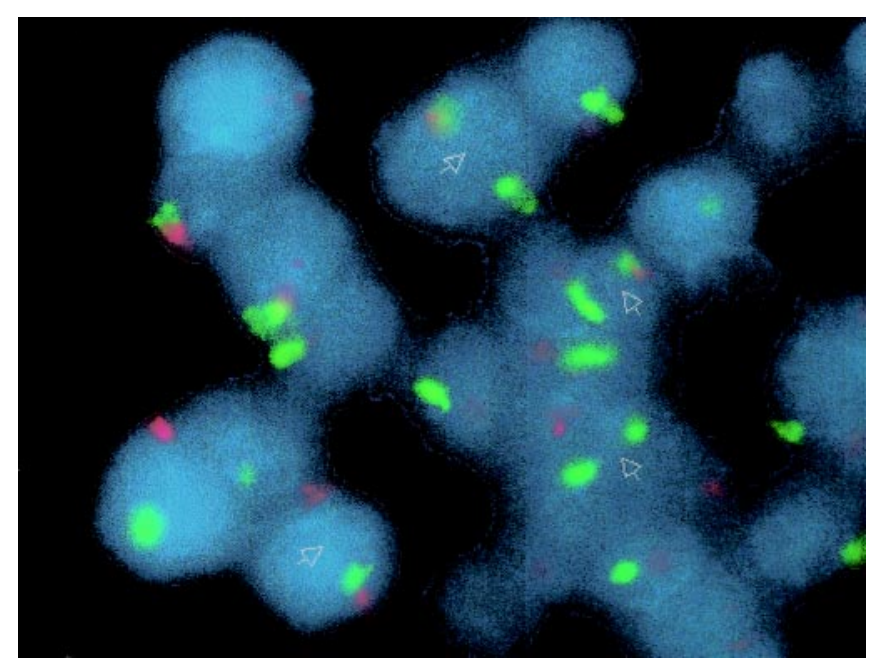

Fig. 1. Fluorescence in situ hybridization (FISH) of the patient's sperm cells: chromosomes 9 (green) and 18 (red). Arrows indicate the cells with disomy 
Diagnosis of disomy or diploidy in sperm cells and trisomy in leukocytes was based on the presence of two or three signals with the same intensity that were separated from each other, with the distance being greater than the diameter of the signal itself. Nullisomies were not directly scored, because their frequency was expected to be equivalent to that of disomies.

In regard to heterochromatin length, we measured the length of the heterochromatin segment and the total length of the chromosome in both chromosomes 9 (Fig. 2), and compared the difference in the relative lengths of the heterochromatin regions between the two chromosomes in our patient and the two normal controls.

Our patient underwent an expanded semen evaluation which included routine light microscopic sperm observations, biochemical evaluation of seminal plasma markers, and a quantitative ultramorphological (QUM) analysis of the sperm cell subcellular organelles (Bartoov et al. 1993, 1994).

\section{Semen evaluation}

Semen observation was performed after the patient had 5 days of sexual abstinence; the observer was unaware of the identity of the patient. Routine semen analysis was performed according to the WHO laboratory manual for semen analysis (World Health Organization [WHO], 1992). Biochemical examinations of the seminal plasma markers were conducted as previously described (Bartoov et al. 1993). Quantitative ultramorphological (QUM) sperm analysis was performed as previously described (Bartoov

Fig. 2. Chromosome 9 of the man carrying the inversion. The arrows indicate the heterochromatic region

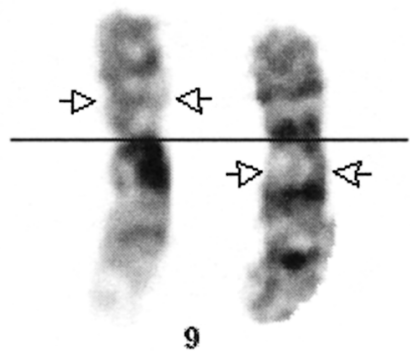

et al. 1994). Briefly, the ultramorphological status of each of the following sperm subcellular organelles was assessed: acrosome; postacrosomal lamina; nucleus, including karyoplasm; neck; axonema; and mitochondrial sheath and outer dense fibers, including the fibrous sheath. Each organelle was observed in parallel by scanning (SEM) and transmission electron microscopy (TEM). The ultrastructure of a subcellular organelle was considered "intact" if it did not exhibit any of the specific organelle malformations described previously (Bartoov et al. 1990). The incidence of each ultramorphological state was quantitatively assessed for 100 cells per sample. The frequencies were expressed as the means of the TEM and SEM observations. A fertility index was calculated. This diagnostic profile is based on a proportional combination of selected parameters and has a discrimination ability of $80 \%$ (Bartoov et al. 1994).

\section{Statistical methods}

Data for the different probes were statistically analyzed by using a two-tailed Fisher's exact test and the $\chi^{2}$ test.

The two-sample $t$-test and nonparametric test were employed for testing differences between the study groups for quantitative parameters and for ratios. Spearman correlations were employed for testing the correlations between the study parameters examined. All tests employed were two-tailed, and $P$ values of $5 \%$ or less were considered statistically significant. The data were analyzed using SAS software (SAS Institute, Cary, NC, USA).

\section{Results}

The hybridization efficiency was in the range of $95 \%$ (with all probes analyzed). There was no difference between the patient carrying the 9 inversion and the normal controls in the proportion of leukocytes with three signals (Table 1). This finding indicates that there is no higher rate of mitotic nondisjunction because of the inversion and the heterochromatin.

The rate of disomy in sperm cells (with all probes analyzed) was significantly higher in the patient when com-

Table 1. Rate of aneuploidy in leukocytes

\begin{tabular}{|c|c|c|c|c|c|c|c|c|}
\hline \multirow[b]{2}{*}{ Subject } & \multicolumn{2}{|c|}{ Chromosome 8} & \multicolumn{2}{|c|}{ Chromosome 18} & \multicolumn{2}{|c|}{ Chromosome 9} & \multicolumn{2}{|c|}{ Chromosomes $\mathrm{X}+\mathrm{Y}$} \\
\hline & $\begin{array}{l}\text { Three } \\
\text { signals }\end{array}$ & $\begin{array}{l}\text { Total no. } \\
\text { of cells }\end{array}$ & $\begin{array}{l}\text { Three } \\
\text { signals }\end{array}$ & $\begin{array}{l}\text { Total no. } \\
\text { of cells }\end{array}$ & $\begin{array}{l}\text { Three } \\
\text { signals }\end{array}$ & $\begin{array}{l}\text { Total no. } \\
\text { of cells }\end{array}$ & $\begin{array}{l}\text { Three } \\
\text { signals }\end{array}$ & $\begin{array}{l}\text { Total no. } \\
\text { of cells }\end{array}$ \\
\hline $\begin{array}{c}46, \mathrm{XY}, \text { inv9, } \\
9 \mathrm{qh}+\end{array}$ & $\begin{array}{l}1 \\
0.19 \%^{\mathrm{a}}\end{array}$ & 203 & $\begin{array}{l}2 \\
0.94 \%\end{array}$ & 212 & $\begin{array}{l}1 \\
0.47 \%\end{array}$ & 212 & $\begin{array}{l}1 \\
0.5 \%\end{array}$ & 200 \\
\hline Control 1 & $0 \%$ & 196 & $\begin{array}{l}1 \\
0.51 \%\end{array}$ & 196 & $\begin{array}{l}1 \\
0.46 \%\end{array}$ & 216 & $\begin{array}{l}1 \\
0.5 \%\end{array}$ & 200 \\
\hline Control 2 & $0 \%$ & 207 & $0 \%$ & 207 & $\begin{array}{l}1 \\
0.45 \%\end{array}$ & 221 & $\begin{array}{l}1 \\
0.49 \%\end{array}$ & 202 \\
\hline
\end{tabular}

${ }^{\mathrm{a}}$ The rate of aneuploidy was estimated by the proportion of the number of cells with three signals from the total cell population (none of the differences was significant) 
Table 2. Rate of disomy in sperm cells

\begin{tabular}{|c|c|c|c|c|c|c|c|c|c|c|c|c|}
\hline \multirow[b]{2}{*}{ Subject } & \multicolumn{2}{|c|}{ Chromosome 8} & \multicolumn{2}{|c|}{ Chromosome 18} & \multicolumn{2}{|c|}{ Chromosome 9} & \multicolumn{2}{|c|}{ Chromosome X } & \multicolumn{2}{|c|}{ Chromosome Y } & \multicolumn{2}{|c|}{$\begin{array}{l}\text { Chromosome } \\
\mathrm{X}+\mathrm{Y}\end{array}$} \\
\hline & Disomy & $\begin{array}{l}\text { Total } \\
\text { no. of } \\
\text { cells }\end{array}$ & Disomy & $\begin{array}{l}\text { Total } \\
\text { no. of } \\
\text { cells }\end{array}$ & Disomy & $\begin{array}{l}\text { Total } \\
\text { no. of } \\
\text { cells }\end{array}$ & Disomy & $\begin{array}{l}\text { Total } \\
\text { no. of } \\
\text { cells }\end{array}$ & Disomy & $\begin{array}{l}\text { Total } \\
\text { no. of } \\
\text { cells }\end{array}$ & Disomy & $\begin{array}{l}\text { Total } \\
\text { no. of } \\
\text { cells }\end{array}$ \\
\hline $\begin{array}{c}\text { 46,XY,inv9 } \\
9 \mathrm{qh}+\end{array}$ & $\begin{array}{l}77 \\
3.6 \%^{\mathrm{a}}\end{array}$ & 2105 & $\begin{array}{l}98 \\
4.5 \%\end{array}$ & 2175 & $\begin{array}{l}116 \\
5.7 \%\end{array}$ & 2004 & $\begin{array}{l}54 \\
2.7 \%\end{array}$ & 1966 & $\begin{array}{l}56 \\
2.9 \%\end{array}$ & 1892 & $\begin{array}{l}50 \\
2.4 \%\end{array}$ & 2004 \\
\hline Control 1 & $\begin{array}{l}7 \\
0.3 \%\end{array}$ & 1997 & $\begin{array}{l}4 \\
0.2 \%\end{array}$ & 1993 & $\begin{array}{l}6 \\
0.3 \%\end{array}$ & 2114 & $\begin{array}{l}8 \\
0.59 \%\end{array}$ & 1886 & $\begin{array}{l}3 \\
0.4 \%\end{array}$ & 1886 & $\begin{array}{l}3 \\
0.1 \%\end{array}$ & 2003 \\
\hline Control 2 & $\begin{array}{l}8 \\
0.39 \%\end{array}$ & 2006 & $\begin{array}{l}8 \\
0.4 \%\end{array}$ & 2000 & $\begin{array}{l}9 \\
0.4 \%\end{array}$ & 2012 & $\begin{array}{l}10 \\
0.4 \%\end{array}$ & 2066 & $\begin{array}{l}8 \\
0.14 \%\end{array}$ & 1934 & $\begin{array}{l}2 \\
0.09 \%\end{array}$ & 2011 \\
\hline
\end{tabular}

${ }^{a}$ The disomy rate was estimated by the proportion of the numbers of cells with disomy from the total cell population

pared to the control rate; $P<0.001$ (Table 2). There seemed to be almost the same number of sperm cells with $\mathrm{X}+\mathrm{Y}$ together as cells with disomies of $\mathrm{X}$ and $\mathrm{Y}$ alone, a finding that indicates the same nondisjunction (ND) rate for the two meiotic divisions (Table 2). The diploidy rate in sperm cells was not increased in the man carrying the inversion and heterochromatin $(P<0.02)$ compared with the control rate $(P<0.01)$.

As for the length of the heterochromatin region - the difference in the relative lengths between the two chromosomes 9 was significantly larger in our patient (mean, $0.10 \pm$ 0.05 SD; Fig. 2) than the difference in the two normal controls (mean, $0.01+0.04 \mathrm{SD} ; P<0.001$ ).

Routine light microscopy (LM) and biochemical examinations revealed normal sperm density $\left(180 \times 10^{6} \%\right.$ ejaculate after 5 days of sexual abstinence), viability ( $65 \%)$, and morphology (46\% normal forms), as well as normal function of the accessory glands. The percentage sperm motility was lower than the laboratory standard, at $38 \%$ vs $40 \%$, respectively; however, $72 \%$ of the motile sperm exhibited progressive motility, with an average speed of $26.4 \mu \mathrm{m} / \mathrm{s}$ at $25^{\circ} \mathrm{C}$. Semen culture was negative. No specific ultramorphological malformations were observed by the QUM method in any of the sperm cell subcellular organelles. The natural male fertility index was normal according to the laboratory standard, at 1.48 vs 0.5 , respectively). Thus, the patient may be classified as a normozoospermic fertile man.

\section{Discussion}

Individuals heterozygous for pericentric inversions may produce, depending on the behavior of the homologous bivalent during meiosis, gametes with the inverted chromosome, a normal one, or with recombinant chromosomes. These individuals are probably prone to fetal wastage, not only because of their recombinant products but also because of the interchromosomal effect (Wang and Hamerton 1979; Neri 1981; Serra et al. 1990).

Our patient's wife's first pregnancy ended in a miscarriage and the second in the termination of a pregnancy with the Down syndrome mosaicism. Based on our findings of a high frequency of disomy in sperm cells in our patient it is possible that the mosaicism originated from meiotic nondisjunction with the postzygotic loss of one chromosome. This assumption concurs with previous reports explaining cases of 21 mosaicism as having a meiotic origin and a later partial trisomy rescue (Robinson et al. 1995).

In our opinion, the addition of the heterochromatin $(\mathrm{qh}+)$ to the normal pericentric inversion made our patient prone to nondisjunction, as expressed in the rate of disomies in his sperm cells. The fact that we did not find a higher rate of aneuploidy in leukocytes is not surprising; during mitosis there is no pairing between homologous chromosomes and, therefore, incomplete pairing interferes only in the process of meiosis. The presence of disomy in FISH for chromosomes $\mathrm{X}$ and $\mathrm{Y}$ alone and $\mathrm{X}$ and $\mathrm{Y}$ together proves that the disturbance affects both meiosis processes I and II. Chromosome 9 was involved more than others (Fig. 1). This may be explained by the difference in the length of its heterochromatic region in this patient, possibly leading to uneven pairing during meiosis I.

Whether an "inversion variant" chromosome can influence its own disjunction is speculative. Willatt et al. (1992) observed that, in 11 reported cases of the rare mosaic trisomy 9 syndrome, 4 occurred in the setting of maternal heterozygosity for the $\operatorname{inv}(9)(\mathrm{p} 11 \mathrm{q} 12)$ variant, suggesting a causal link. Partial trisomy 9 has been associated with a parental inv(9)(p11q12/3) (Kaiser 1984; Stamberg and Thomas 1986). It is important to keep in mind that these reports involve only a minority of the many individuals heterozygous for inv(9) (a common finding, that is assessed to occur in up to $1 \%$ of the population). Inversions in chromosome 9 were also found in cytogenetic studies in men suffering from infertility.

Martin and Rademaker (1990) analyzed chromosome complement in sperm taken from 98 men, using a human sperm/hamster egg fusion technique. Among individual autosomes, only chromosome 9 showed an increased frequency of hyperhaploidy.

Based on the findings of our study, it may be possible to attribute the abnormality in chromosomal behavior to the difference in the length of the heterochromatin of chromosome 9, which was found in our patient and in some of the individuals in other reports (Ford et al. 1982; Fryns et al. 1984; Wang and Hamerton 1979; Serra et al. 1980). The presence of a centric heterochromatin has been considered 
to be a risk factor for the development of nondisjunction and a functional explanation for the finding of a higher incidence of hyperhaploidy in chromosomes 1, 9, and 16 (Martin 1991; Geraedts and Pearson 1973; Serra et al. 1990).

The role of pericentric inversion of chromosome 9, inv(9), diagnosed in the products of conception following miscarriages is still very controversial. Indeed, although inv(9) has been associated with repeated spontaneous abortions in several families (Boue et al. 1975), studies on unselected series of couples have usually failed to demonstrate a relationship between inv(9) and repeated abortions (Hemming and Burns 1979; Carothers et al. 1982).

We speculate that the difference in the natural history of patients with this kind of 'abnormality' depends on the difference in the length of the heterochromatic region, and that a small difference may not have the same effect as a greater difference, especially when it comes with an inversion: the common $9 \mathrm{q}$ inversion with a significant difference in the length of the C-heterochromatin of the two chromosomes 9 increases the risk for meiotic nondisjunction (Serra et al. 1980).

To conclude, it is well known that the effect of inv9(qh) is highly variable, and may even vary in members of the same family. However, no satisfactory explanation can be found in the literature for this observation. Based on our finding, we speculate that the variability in the biologic behavior in carrier individuals is dependent on the presence or absence of a significant difference in the length of the heterochromatin of the specific chromosome.

\section{References}

Bartoov B, Eltes F, Soffer Y, Ron-El R, Langsam J, Lederman H, Har-Even D, Kedem P (1990) Ultramorphological characteristics of human sperm cells. In: Mashiach S, Ben-Rafael Z, Laufer N, Schenkler JG (eds) Advances in in vitro fertilization and assisted reproduction technologies. Plenum, New York, pp 493-513

Bartoov B, Eltes F, Pansky M, Lederman H, Caspi E, Soffer Y (1993) Estimating fertility potential via semen analysis data. Hum Reprod 8:65-70

Bartoov B, Eltes F, Pansky M, Langzam J, Reichart M, Soffer Y (1994) Improved diagnosis of male fertility potential via a combination of quantitative ultramorphology and routine semen analysis. Hum Reprod 9:2069-2070

Blumberg BD, Shulkin JD, Rotter JI, Mohandas T, Kaback MM (1982) Minor chromosomal variants and major chromosomal anomalies in couples with recurrent abortion. Am J Hum Genet 34:948-960

Boue J, Faillemite JL, Hazael-Massieux P, Leonard, Boue A (1975) Association of pericentric inversion of chromosome 9 and reproductive failure in ten unrelated families. Hum Genet 30:217-224

Carothers AD, Buckton KE, Collye S, de Mey R, Frackiewicz A, Piper J, Smith L (1982) The effect of variant chromosomes on reproductive fitness in man. Clin Genet 21:280-289

Colls P, Blanco J, Martinez-Pasarell O, Vidal F, Egozcue J, Marquez C, Guitart M, Templado C (1997) Chromosome segregation in a man heterozygous for a pericentric inversion, inv(9)(p11q13), analyzed by using sperm karyotyping and two-color fluorescence in situ hybridization on sperm nuclei. Hum Gene 99:761-765

De La Chapelle A, Schroder J, Stenstrand K, Fellman J, Herva M, Saarni I, Anttolainen I, Tallila I, Tervila LH, Tallqvist G, Robson EB, Cook PJL, Sanger R (1974) Pericentric inversions of human chromosomes 9 and 10. Am J Hum Genet 26:746-766
Ford JH, Lester P (1982) Factors affecting the displacement of human chromosomes from the metaphase plate. Cytogenet Cell Genet 33:327-332

Ford JH, Callen DF, Jahnke AB, Roberts CG (1982) Within pair differences of human chromosome $9 \mathrm{C}$-bands associated with reproductive loss. Hum Genet 61:360-363

Fryns JP, Kleczkowska A, Kubien E (1984) Cytogenetic survey in couples with recurrent fetal wastage. Hum Genet 65:336354

Gabriel-Robez O, Ratomponiria C, Croquette M, Maetz JL, Rumpler CY (1987) Reproductive failure and pericentric inversion in man. Andrologia 19:662-669

Gardner RJM, Sutherland GR (1996) Chromosome abnormalities and genetic counseling. Oxf Monogr Med Genet 29:139-152

Geraedts J, Pearson P (1973) Specific staining of the human No. 1 chromosome in spermatozoa. Hum Genet 20:171-173

Guttenbach M, Engel W, Schmid M (1997) Analysis of structural and numerical chromosome abnormalities in sperm of normal men and carriers of constitutional chromosome aberrations. A review. Hum Genet 100:1-21

Hemming L, Burns C (1979) Heterochromatic polymorphism in spontaneous abortions. J Med Genet 16:358-362.

Holbek S, Friedrich U, Lauritsen JG, Therkelsen AJ (1974) Marker chromosomes in parents of spontaneous abortuses. Hum Genet 25:61-64

Kaiser P (1984) Pericentric inversion: problems and significance for clinical genetics. Hum Genet 68:1-47

Maes A, Staessem C, Hens L, Vamos E, Kirsch-Volders M, Lauwers MC, Defrise-Gussenhoven E, Susanne C (1983) C heterochromatin variation in couples with recurrent early abortions. J Med Genet 30:350-356

Martin RH (1991) Cytogenetic analysis of sperm from a man heterozygous for a pericentric inversion, inv(3)(p25q21). Am J Hum Genet 48:856-861

Martin RH (1999) Sperm chromosome analysis in a man heterozygous for a paracentric inversion of chromosome 14(q24.1q32.1). Letters to the Editor. Am J Hum Genet 64:1480-1484

Martin RH, Rademaker A (1990) The frequency of aneuploidy among individual chromosomes in 6821 human sperm chromosome complements. Cytogenet Cell Genet 53:103-107

Martin RH, Chernos JE, Lowry RB, Pattinson HA, Barclay L, Ko E (1993) Analysis of sperm chromosome complements from a man heterozygous for a pericentric inversion, inv(8)(p23q22). Cytogenet Cell Genet 62:199-202

Martin RH, Chernos JE, Lowry RB (1994) Analysis of sperm chromosome complements from a man heterozygous for a pericentric inversion of chromosome 1. Hum Genet 93:135-138

Navarro J, Benet JR, Martorell C, Templado C, Egozcue J (1993) Segregation analysis in a man heterozygous for a pericentric inversion of chromosome 7 (p13;q36) by sperm chromosome studies. Am J Hum Genet 53:214-219

Neri G (1981) Pericentric inversion of chromosome 9 and Down's syndrome: a retrospective and prospective family survey. Clin Genet 19:526-527

Nielsen J, Friedrich U, Hreidarsson AB, Zeuthen E (1974) Frequency of $9 \mathrm{qh}+$ and risk of chromosome aberration in the progeny of individuals with 9qh+. Hum Genet 21:211-216

Robinson WP, Binkert F, Bernasconi F, Lorda-Sanchez I, Werder EA, Schinzel AA (1995) Molecular studies of chromosomal mosaicism: relative frequency of chromosome gain or loss and possible role of cell selection. Am J Hum Genet 56:444-451

Rosenmann A, Segal S, Palti Z, Cohen MM (1977) Chromosomes in familial primary sterility and in couples with recurrent abortions and stillbirth. Isr J Med Sci 13:1131-1132

Serra A, Bova R, Neri G, Brahe C, Tedeschi B (1980) Potential effects of pericentric inversion of the heterochromatic region of chromosome 9 (abstract). Clin Genet 18:87

Serra A, Brahe C, Millington-Ward A, Neri G, Tedeschi B, Tassone F, Bova R (1990) Pericentric inversion of chromosome 9: prevalence in 300 Down syndrome families and molecular studies of nondisjunction. Am J Med Genet 7:162-168

Spriggs EL, Rademaker AW, Martin RH (1995) Aneuploidy in human sperm: results of two- and three-color fluorescence in situ hybridization using centromeric probes for chromosomes 1, 12, 15, 18, X, and Y. Cytogenet Cell Genet 71:47-53 
Stamberg J, Thomas GH (1986) Unusual supernumerary chromosomes: types encountered in a referred population, and high incidence of associated maternal chromosome abnormalities (abstract). Am J Hum Genet 39:133

Tibiletti MG, Simoni G, Terzoli GL, Romitti L, Fedele L, Candiani GB (1981) Pericentric inversion of chromosome 9 in couples with repeated spontaneous abortion. Acta Eur Fertil 12:245248

Trunca O, Opitz JM (1977) Pericentric inversion of chromosome 14 and the risk of partial duplication of $14 q(14 q 13-14 q$ ter $)$. Am J Med Genet 1:217-228

Tsenghi CH, Metaxulou C, Kalpini-Mavrou A, Strataki-Benetou M, Matsaniotis N (1981) Parental chromosome translocations and fetal loss. Obstet Gynecol 58:456-458
Wang HS, Hamerton JL (1979) C-Band polymorphisms of chromosomes 1,9 , and 16 in four subgroups of mentally retarded patients and a normal control population. Hum Genet 51:269-275

Willatt LR, Davison BCC, Goudie D, Alexander J, Dyson HM, Jenks PE, Ferguson-Smith ME (1992) A male with trisomy 9 mosaicism and maternal uniparental disomy for chromosome 9 in the euploid cell line. J Med Genet 29:742-744

Winsor EJT, Palmer CG, Ellis PM (1978) Meiotic analysis of a pericentric inversion, inv(7)(p22q32), in the father of a child with a duplication-deletion of chromosome 7. Cytogenet Cell Genet 20:169-184

World Health Organization (WHO) (1992) Laboratory manual for the examination of human semen and semen-cervical mucus interaction, 3rd edn. Cambridge University Press, Cambridge, pp 43-45 